\title{
The Mediating Role of Satisfaction in the Relationship between Service Quality and Loyalty: Case Study in PT Asuransi XYZ Indonesia.
}

\author{
Roby Nurismartian ${ }^{1 *}$, Prof. Ir. Hendra Michael Roy Sembel, MBA., Ph.D., CSA ${ }^{2}$ \\ ${ }^{1,2}$ Sekolah Tinggi Manajemen IPMI, DKI Jakarta 12750, Indonesia
}

\begin{abstract}
A B S T R A C T
The objective of this study is to analyze the relationship of service quality on agents' satisfaction, service quality on agents' loyalty, and satisfaction on loyalty when they used the insurance portal XYZNet as a digital tool provided by PT Asuransi XYZ Indonesia for their agents to increase market share in retail business in Indonesia. Where the portal was facing the challenge of the low number of usages. This study used a quantitative approach, involved 100 respondents which have minimum five times using this portal as samples. The analysis technique used in this study is Partial Least Square (PLS) Structural Equation Modeling (SEM), with the help of SmartPLS version 3.2.8 software. The results indicated that service quality positively influenced agents' satisfaction, satisfaction also positively influenced agents' loyalty. However, service quality did not significantly influence agents' loyalty. The finding also indicated that satisfaction was a significant variable that mediated the relationship between service quality and loyalty. The study gives positive impact to the future researchers to do similar study. Furthermore, the finding could help PT Asuransi XYZ and insurance company in general to improve their service quality.
\end{abstract}

ART ICLE INFO

Article History:

Received : 20-11-2019

Revised : 28-02-2020

Accepted : 28-02-2020

Published : 02-03-2020

Keywords:

Service Quality,

Satisfaction,

Loyalty,

E-S-QUAL, PLS
*Corresponding Author E-mail: roby.nurismartian@gmail.co.id

Copyright @ 2020 Authors. This is an open access article distributed under the Creative Commons Attribution License, which permits unrestricted use, distribution, and reproduction in any medium, provided the original work is properly cited.

\section{INTRODUCTION}

The world entering industrial revolution 4.0, which characterized by digital economy, big data and automation. This digital revolution has transformed the way companies interact with customers. It is happened all around the globe, including Indonesia as well. Based on research from Accenture in the next five years, almost all the insurance executive's respondents expect the insurance industry to be transformed by digital technologies (Struntz, Poppleton and Lees, 2019). This digitalization not only affect one or two part process or service but almost all parts of the insurance value chain (Catlin, Khanna, Lorenz and Sultan, 2016). So, it is not surprising, many 
insurance companies continue to develop their digital services, in order to maintain and strengthen their business Indonesia. PT Asuransi XYZ Indonesia, a joint venture general insurance, is among the insurance companies which strongly commit to digitalize its business process. PT Asuransi XYZ Indonesia needs to digitalize its business process to penetrate retail markets, which is still the blue ocean in the general insurance market.

Following its ambition in retail market, PT Asuransi XYZ Indonesia has launched a portal, named "XYZNet", in 2017 to support their agencies' sales process. However only $26.2 \%$ from 1487 active agents are actively submit insurance businesses through XYZNet. Furthermore, based on an internal analysis of portal use, the authors also found a decrease in portal usage for the same agent, which indicates a challenge in agent loyalty in using the portal as their tool for registering business.

Having strong aim to penetrate retail market in Indonesia, PT Asuransi XYZ Indonesia relies on these agents to achieve the aim. Therefore, a study must be conducted by PT Asuransi XYZ Indonesia to measure how the service quality of its digital vehicle, XYZNet, can satisfy the agents at first and then at the end can trigger the loyalty of the agents.

Based on the problem statement proposed in this research, it can be concluded that the objectives of this study are; (1) To analyze the relationship of service quality of XYZNet on agents' satisfaction, (2) To analyze the relationship of service quality of XYZNet on agents' loyalty, (3) To analyze the relationship of satisfaction to loyalty, and (4) To analyze the relationship of satisfaction as mediator between service quality and satisfaction.

\section{LITERATURE REVIEW}

Insurance is a risk control method carried out by transferring the risk from one party (consumers) to other party (insurance companies) (Muhammad, 2006). Under the Undang-Undang Republik Indonesia Nomor 40 tentang Perasuransian, 2014,
Insurance is a written agreement between the insurance company and the policyholder under which, in return of a premium, the insurance company agrees to either: (a) Provide compensation due to losses, damage, costs, loss of revenue or legal liability to any third party that may be suffered by the policyholder, or (b) Provide payment due to the death/life of the insured party with a benefit of which value has been determined and/or based on the result of fund management.

Marketing is the process by which the companies create added value for the customers and build strong relationships with the customers. The objective is to put together value from the customers in return (Kotler and Armstrong, 2014). Marketing can also be interpreted as a social process that involves important activities where individuals or organizations gather what they need and want in the exchange process, which also serves to develop a sustainable exchange relationship (Mullins, Ahearne, Lam, Hall and Boichuk, 2014). Service marketing activities consists of relationship activities, interaction activities, service value activities and service resource activities (Link and Hildebrand, 1993), then it can be defined that service marketing as the connection between customer and the organization (Yazid, 2008). However, the relationship between the organization and its customers will work well, if all efforts of the marketing process are consumer-oriented.

Kotler and Keller (2016), mentioned that service quality is the attitude and comparison between expectations and perceived reality. This refers to the customer's evaluation of the advantages of an entity. Zeithaml, Parasuraman and Malhotra (2002), mentioned if e-service quality as the extent to which a website provides shopping, purchasing and shipping facilities effectively and efficiently. In the same context, other researchers define the e-service quality as the experience of customers who use services through electronic channels provided without human intervention. In this case, the internet is considered as the main channel for providing electronic services (Lu, Shambour, 
$\mathrm{Xu}$, Lin and Zhang, 2010; Parasuraman, Zeithaml and Malhotra, 2005; Sousa and Voss, 2006).

Numerous studies have been conducting in developing the scale for measuring e-service quality. Loiacono, Watson and Goodhue (2002) created scale called WebQual consist of 12 dimensions to measure website quality. Next, Barnes and Vidgen (2002) created also called WebQual, to measure site's quality and has five factors. Yoo and Donthu (2001) also developed nine item scale for measuring site quality called SITEQUAL. Wolfinbarger and Gilly (2003) used online and offline survey to develop 14 item scale in four dimensions called eTailQ. Then Zeithaml, Parasuraman and Malhotra $(2000,2002)$ develop e-SERVQUAL to measure e-service quality through seven dimensions. Through latest research, there are new method to measure e-service quality. This measurement consists of four dimensions; (1) fulfillment, (2) efficiency, (3) privacy and (4) system availability. This proposed method called E-SQUAL (Parasuraman et al., 2005a).

E-satisfaction has been an important factor that has been discussed in a variety of literatures related to marketing in recent times (Evanschitzky, Iyer, Hesse and Ahlert, 2004; Szymanski and Hise, 2000; Yi and La, 2004). Based on the conceptualization of Oliver $(1997,2010)$, who viewed satisfaction as every transaction experienced that evaluated by the customer, this study defines e-satisfaction as a pleasant fulfillment accumulates over several transaction experiences which results in the formation of an overall evaluation of online retailers.

This study defines e-loyalty as customers' favorable attitude as a result from their experience with eservices resulting on buying behavior repetition, based on result study from Anderson and Srinivasan (2003). Based on result study from Reicheld, Markey and Hopton (2000), e-loyalty has been proved to increase profits for online retailers through certainty over the commitment of old customers and reduce the cost of getting new customers.
Based on above described literature the following hypotheses were proposed for this study:

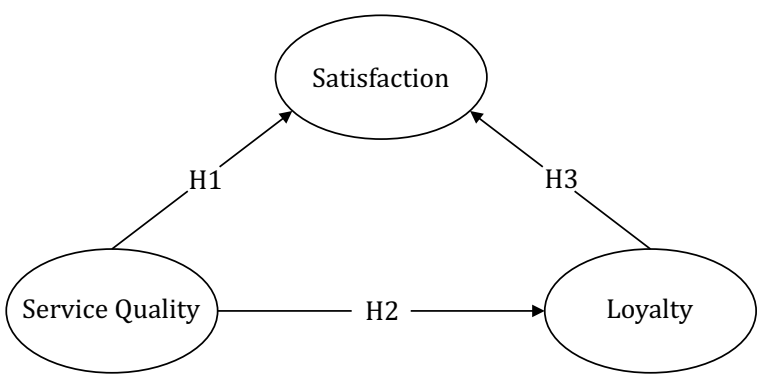

Figure 1. Conceptual Structure

\section{Service Quality and Satisfaction}

Zeithaml et al. (2002) mentioned if e-service quality as the extent to which a website provides shopping, purchasing and shipping facilities effectively and efficiently. Lee and Lin (2005) found that e-service quality dimensions affect customer satisfaction. Supported by the research by Lin and Sun (2009) that the service quality provided by the website positively affect customer e-satisfaction, similar result is also presented by Ghalandari (2012), Gounaris, Dimitriadis and Stathakopoulos (2010), Kundu and Datta (2015), Purnamasari (2018), that e-service quality strongly affected customer e-satisfaction, emphasized by Sharma (2017) if e-service quality has a direct and an indirect impact on e-satisfaction.

$\mathbf{H}_{\mathbf{1}}$ : Service quality positively influence agents' satisfaction.

\section{Service Quality and Loyalty}

E-loyalty is favorable attitude from the customers as a result from their experience with e-services resulting on buying behavior repetition, based on result study from Anderson and Srinivasan (2003). Lin and Sun (2009) found that the service quality provided by the website positively affect customer e-loyalty. Purnamasari (2018) in her research also found that e-service quality has significant and positive effect on e-loyalty.

$\mathbf{H}_{\mathbf{2}}$ : Service quality positively influence agents' loyalty.

\section{Satisfaction and Loyalty}

E-satisfaction can be considered as a favorable feeling from a customer related to its relationship 
with a company's e-service. This study defines esatisfaction as a pleasant fulfillment accumulates over several transaction experiences which results in the formation of an overall evaluation of online retailers, based on Oliver $(1997,2010)$ concept. Lin and Sun (2009) in their research found if customer e-satisfaction positively affect customer e-loyalty. Ghalandari (2012) also found that esatisfaction influences positively on e-loyalty. Then Sharma (2017) concluded that e-satisfaction affects positively on e-loyalty.

$\mathbf{H}_{\mathbf{3}}$ : Satisfaction positively influence loyalty.

\section{Satisfaction as mediator for Service Quality and Loyalty}

The role of satisfaction as a mediator between service quality and loyalty also existed in previous research, Sharma (2017) in his research found that satisfaction has significant impact as a mediator for service quality and customer loyalty. Purnamasari (2018) in her research also found that e-satisfaction mediated positively between service quality and loyalty.

$\mathbf{H}_{4}$ : Satisfaction mediates the relationship between service quality and loyalty.

\section{RESEARCH METHOD}

The variables used in this study are adapted from previous studies. This study using Service Quality scale from Parasuraman, Zeithaml and Malhotra (2005b) consist of four dimensions; (1) fulfillment, (2) efficiency, (3) privacy and (4) system availability. Meanwhile, other variables adapted from a number of the previous studies. Satisfaction adapted from Lin and Sun (2009), while Loyalty from Zeithaml, Berry and Parasuraman (1996).

To achieve the objectives, this study uses primary and secondary data. Primary data was obtained by means of questionnaires, and secondary data was retrieved from the related literature. The questionnaires distributed to the insurance agents in Jawa and Bali who have made minimum fivetime transaction using the portal. In this study, the questions are more on measuring quantitative causal effect, or deductive study between e-service quality, e-satisfaction and e-loyalty. Causal research is research that aims to examine the causal relationship between two or more variables (Abdillah and Hartono, 2015), so that it can explain the effect of changes in the variation of values in one variable to changes in value variations in one or more other variables (Silalahi, 2009).

In this study the sampling technique used is probability sampling with cluster sampling technique. According to Sugiyono (2016) cluster sampling is a technique used to determine samples when the object to be studied or data sources are very broad. Then the sampling is based on a predetermined population group, i.e.: (1) Agents registered in the portal XYZNet during 2018-2019 (2) Agents who have used services from the XYZNet portal during 20182019, and (3) The agent mentioned above has used the services of the XYZNet portal at least five times. Based on above sampling technique, it can be known that the number of samples used in this study is 100 samples.

The data collected, was analyzed using SEM-PLS (Structural Equation Modeling-Partial Least Square) technique in SmartPLS 3.2.8 software program.

\section{RESULT AND DISCUSSION}

This study uses 100 respondents who have made minimum five transactions using the portal in Jawa and Bali. The respondents' demographic characteristics are presented in Table 1 below:

Table 1. The Respondent Demographic Characteristic

\begin{tabular}{cccc}
\hline Profile & Description & N & \% \\
\hline Gender & Male & 70 & $70 \%$ \\
& Female & 30 & $30 \%$ \\
\hline Age & $26-35$ years old & 18 & $18 \%$ \\
& $36-45$ years old & 30 & $30 \%$ \\
& $46-55$ years old & 30 & $30 \%$ \\
& $>55$ years old & 22 & $22 \%$ \\
\hline \multirow{2}{*}{ Education } & Senior High School & 20 & $20 \%$ \\
& Diploma & 28 & $28 \%$ \\
& Bachelor & 48 & $48 \%$ \\
& Master & 4 & $4 \%$ \\
\hline Domicile & Bandung & 18 & $18 \%$
\end{tabular}




\begin{tabular}{ccc} 
Denpasar & 14 & $14 \%$ \\
Jabodetabek & 34 & $34 \%$ \\
Semarang & 14 & $14 \%$ \\
Solo & 10 & $10 \%$ \\
Surabaya & 6 & $6 \%$ \\
Yogyakarta & 4 & $4 \%$ \\
\hline Total Sample & 100 & $100 \%$ \\
\hline
\end{tabular}

The results of the factor analysis will be used in the formation of structural models. The structural model picture to visualize the relationship between service quality, satisfaction and loyalty is presented in the figure below:

The first evaluation on the outer model is convergent validity. To measure convergent validity that is by looking at the value of each outer loading. An indicator is said to meet convergent validity if it has an outer loading value more than 0.5. Here are the outer loading values of each indicator on the research variable:

Table 2. Convergent Validity Result

\begin{tabular}{lcc}
\hline Name of Variable & Indicator & Loading Factor \\
\hline Service Quality & SQ1 & 0.841 \\
\cline { 2 - 3 } & SQ2 & 0.832 \\
\cline { 2 - 3 } & SQ3 & 0.705 \\
\hline Satisfaction & SQ4 & 0.738 \\
\cline { 2 - 3 } & SA1 & 0.751 \\
\cline { 2 - 3 } & SA2 & 0.878 \\
\hline Loyalty & SA3 & 0.908 \\
\cline { 2 - 3 } & SA4 & 0.853 \\
\cline { 2 - 3 } & LO1 & 0.880 \\
\cline { 2 - 3 } & LO2 & 0.860 \\
\cline { 2 - 3 } & LO3 & 0.791 \\
\hline
\end{tabular}

The test result shown in table 2 above coming from software PLS processing. Based on that data, it can be seen that all dimension and indicators have passed the requirement for loading value, which should be above 0.5 . Therefore, it can be concluded that the whole collected data is valid and it has good convergent validity.

The second evaluation on the outer model is discriminant validity. To measure discriminant validity, cross loading values can be used. An indicator is said to meet discriminant validity if the cross-loading indicator value for the variable is the largest compared to the other variables. The cross-loading values in this study are presented in the following table:

Table 3. Discriminant Validity Result

\begin{tabular}{cccc}
\hline & Loyalty & Satisfaction & Service Quality \\
\hline LO1 & 0.880 & 0.661 & 0.592 \\
\hline LO2 & 0.860 & 0.445 & 0.416 \\
\hline LO3 & 0.791 & 0.355 & 0.382 \\
\hline L04 & 0.862 & 0.810 & 0.569 \\
\hline SA1 & 0.526 & 0.751 & 0.584 \\
\hline SA2 & 0.600 & 0.878 & 0.632 \\
\hline SA3 & 0.666 & 0.908 & 0.675 \\
\hline SA4 & 0.661 & 0.853 & 0.503 \\
\hline SQ1 & 0.517 & 0.487 & 0.841 \\
\hline SQ2 & 0.498 & 0.521 & 0.832 \\
\hline SQ3 & 0.431 & 0.512 & 0.705 \\
\hline SQ4 & 0.431 & 0.668 & 0.738 \\
\hline
\end{tabular}

Based on table 3 the discriminant validity from each construct that correlated with its indicators is higher compared to other constructs. Therefore, it can be concluded that constructs in this study

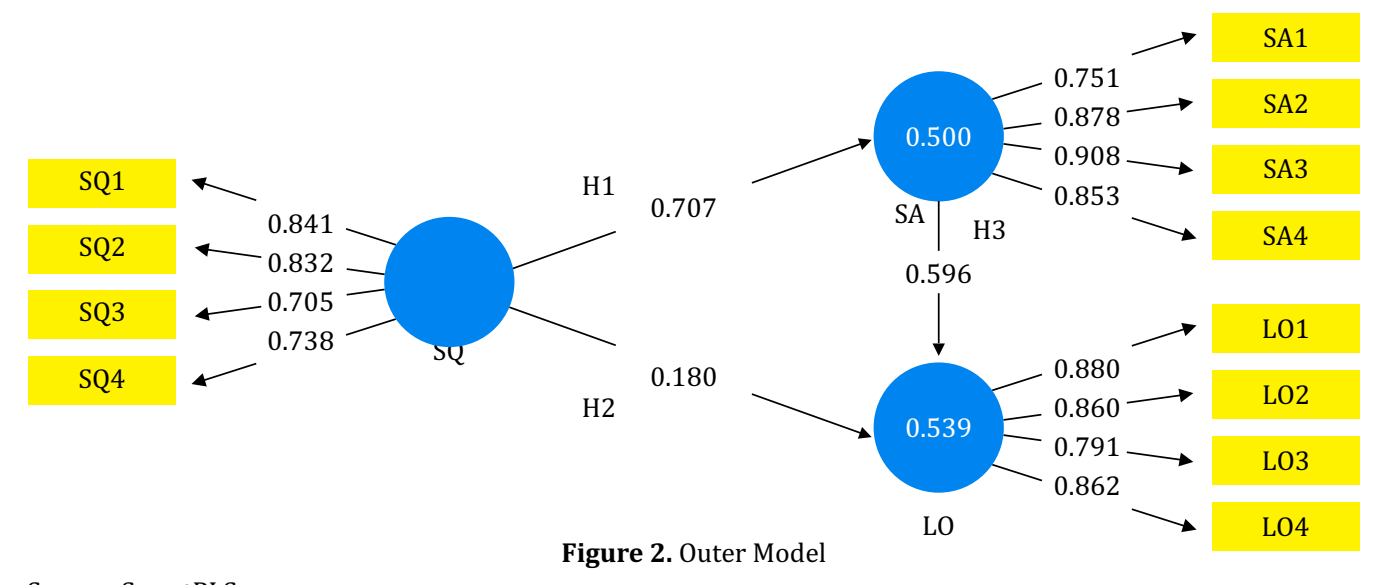

Source: SmartPLS 
has good discriminant validity.

The last evaluation on the outer model is composite reliability. Composite reliability tests the reliability value of indicators in a construct. A construct or variable is said to meet composite reliability if it has a composite reliability value more than 0.7. Here is the composite reliability value of each construct or variable:

Table 4. Composite Reliability Result

\begin{tabular}{lc}
\hline Name of Variable & Composite Reliability \\
\hline Service Quality & 0.862 \\
\hline Satisfaction & 0.912 \\
\hline Loyalty & 0.912 \\
\hline
\end{tabular}

The table 4 above shows that the composite reliability value of each study variable is more than 0.7. Thus, it can be concluded that each variable meets the composite reliability. Structural model testing was done to see the coefficient of determination and path coefficient estimation. The path coefficient result model picture to visualize the relationship between service quality, satisfaction and loyalty is presented in the figure below:

The first evaluation on the inner model is seen from the R-Square value or the coefficient of determination. Based on the value of R-square adjusted in table 5 , in which each has been multiplied by $100 \%$, produces a determination coefficient value of loyalty of $53.0 \%$. Such value of the coefficient of determination is categorized as substantial. Such value shows that $53.0 \%$ of the variation in loyalty values can be explained by service quality and satisfaction, while the remaining $47.0 \%$ can be explained by other variables outside the analysis model. The coefficient of determination of satisfaction produces a value of $49.5 \%$. It is categorized as moderate. It shows that $49.5 \%$ of variation in satisfaction value can be explained by service quality, while the remaining $50.5 \%$ is explained by other variables outside the analysis model.

Table 5. R-Square Result

\begin{tabular}{lcc}
\hline Name of Variable & R Square & R Square Adjust \\
\hline Loyalty & 0.539 & 0.530 \\
\hline Satisfaction & 0.500 & 0.495 \\
\hline
\end{tabular}

The path coefficient estimation is evaluated based on the value of T-statistics. The path coefficient estimation shows the estimation value, which describes the relation between latent variables gained by bootstrapping procedure. The measurement items used can be classified as significant if the value of T-statistics is higher than 1.64 on the error margin of 5\% (Ghozali, 2014).

Table 6. Path Coefficient

\begin{tabular}{lccc}
\hline Hypothesis & $\begin{array}{c}\text { Original } \\
\text { Sample (0) }\end{array}$ & $\begin{array}{c}\text { T- } \\
\text { Statistic }\end{array}$ & $\begin{array}{c}\text { P- } \\
\text { Values }\end{array}$ \\
\hline Service Quality $\rightarrow$ Satisfaction & 0.707 & 14.566 & 0.000 \\
\hline Service Quality $\rightarrow$ Loyalty & 0.180 & 1.415 & 0.079 \\
\hline Satisfaction $\rightarrow$ Loyalty & 0.596 & 5.267 & 0.000 \\
\hline
\end{tabular}

Based on table 6 above, the data can be elaborated as follows:

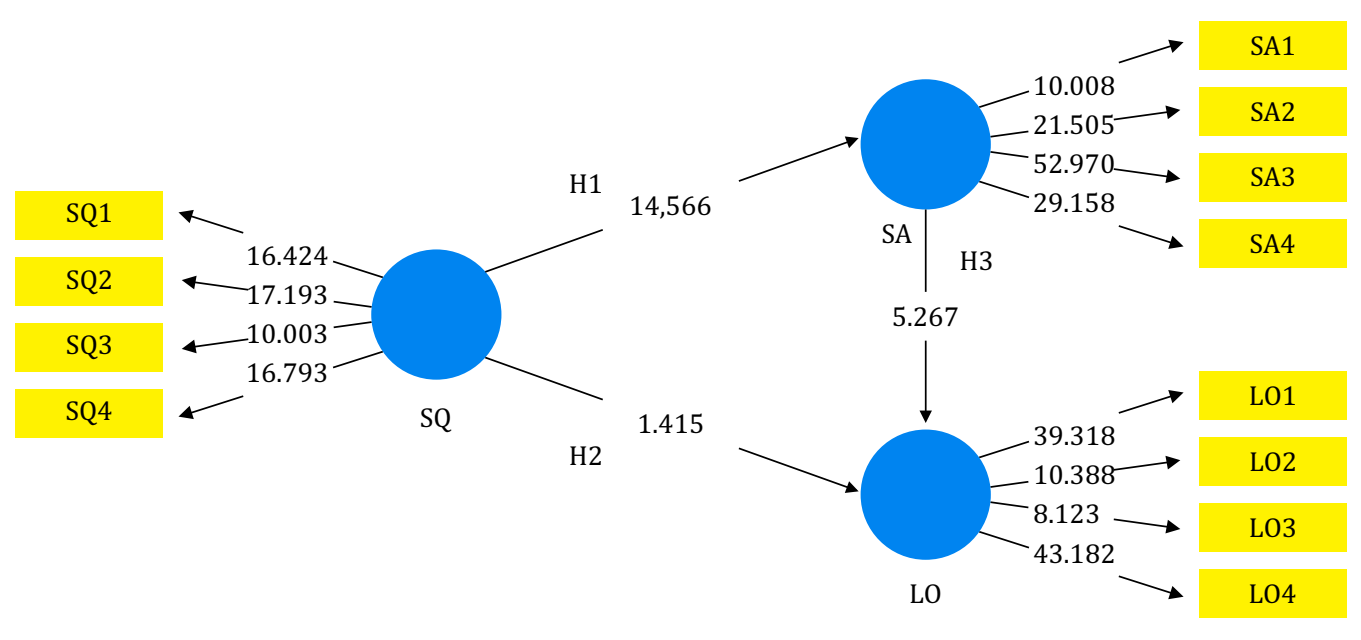

Figure 3. Path Coefficient Result Model 
The first hypothesis proposed is that service quality positively influence agents' satisfaction. The result of SEM analysis obtained from the value of Original sample is 0.707 (positive), $\mathrm{T}$ statistic is 14.566 (more than 1.64) and the pvalue is 0.000 (less than 0.05 ) or considered significant. Therefore, hypothesis 1 is accepted. It shows that the better the service quality provided by portal XYZNet, the higher the satisfaction of the agents. This result is consistent with the research conducted by Lee and Lin (2005) in which they found that e-service quality dimensions affect customer satisfaction. This statement also supported by the research by Lin and Sun (2009) that the service quality provided by the website positively affect customer esatisfaction, similar result is also presented by Ghalandari (2012), Gounaris et al. (2010), Kundu and Datta (2015), Purnamasari (2018), that eservice quality strongly affected customer esatisfaction, emphasized by Sharma (2017) if eservice quality has a direct and an indirect impact on e-satisfaction.

The second Hypothesis presented is service quality positively influence agents' loyalty. The result of SEM analysis obtained from the value of original sample is 0.180 (positive), T Statistic is 1.415 (less than1.64) and the p-value is 0.079 (more than 0.05 ) but less than 0.1 or considered marginally significant. However even it considered marginally significant, hypothesis 2 is rejected. It shows that the higher the service quality provided by portal XYZNet, it is not directly give higher agents' loyalty. This result is inconsistent with the research conducted by Lin and Sun (2009) where they found that the service quality provided by the website positively affect customer e-loyalty, and similar with Purnamasari (2018) in her research also found that e-service quality has significant and positive effect on e-loyalty. It also shows that loyalty from the agents was not automatically coming from various services provided from the portal, means company strategy to create sophisticated services in order to increase agents loyalty is less accurate.

The third hypothesis proposed is that satisfaction positively influence loyalty. The result of SEM analysis obtained from the value of the original sample is 0.596 (positive), $\mathrm{T}$ Statistic is 5.267 (more than 1.64) and the p-value is 0.000 (less than 0.05 ) or considered significant. Therefore, hypothesis 3 is accepted. It shows that the higher the agents' satisfaction, the higher loyalty of the agents in using portal XYZNet. This result consistent with the result from Lin and Sun (2009) in their research they found that if customer e-satisfaction positively affect customer e-loyalty. This statement also supported by Ghalandari (2012) which also found that e-satisfaction influences positively on e-loyalty. Then Sharma (2017) concluded that e-satisfaction affects positively on e-loyalty.

Table 7. Indirect Effect

\begin{tabular}{lccc}
\hline Hypothesis & $\begin{array}{c}\text { Original } \\
\text { Sample (0) }\end{array}$ & $\begin{array}{c}\text { T- } \\
\text { Statistic }\end{array}$ & $\begin{array}{c}\text { P- } \\
\text { Values }\end{array}$ \\
\hline Service Quality $\rightarrow$ Loyalty & 0.421 & 4.487 & 0.000 \\
\hline
\end{tabular}

The fourth hypothesis proposed is that satisfaction mediates the relationship between service quality and loyalty. From the results indirect effect of the PLS analysis in table 4.7 above, it was found that service quality positively affected loyalty through satisfaction with a significance of $\mathrm{T}$ Statistic is 4.487 (more than 1.64) and p-value is 0,000 (less than 0.05 ) or considered significant. Therefore hypothesis 4 is accepted. It was consistent with previous research, Sharma (2017) in his research found that satisfaction has significant impact as a mediator for service quality and customer loyalty. Purnamasari (2018) in her research also found that e-satisfaction mediated positively between e-service quality and e-loyalty. It shows that e-satisfaction have essential roles as mediator between e-service quality and e-loyalty. Meaning, agents' loyalty will increase if they satisfied with services provided by the XYZNet portal.

\section{CONCLUSION}

Based on the analysis and test on the hypothesis, which has been done, the result of the research can be concluded as follows:

First hypothesis which stated that there is a positive influence of service quality on agents' 
satisfaction is accepted. It means that the better the service quality provided by portal XYZNet, the higher the satisfaction of the agents.

Second hypothesis which stated that there is a positive influence of service quality on agents' loyalty is rejected. It shows that the higher the service quality provided by portal XYZNet, it is not directly give higher agents' loyalty.

Third hypothesis which stated that there is a positive influence of agents' satisfaction on loyalty is accepted. It means that the higher the agents' satisfaction, the higher loyalty of the agents in using portal XYZNet.

Fourth hypothesis which stated that satisfaction mediates the relationship between service quality and loyalty is accepted. It shows that satisfaction have essential roles as mediator between service quality and loyalty. Meaning, agents' loyalty will increase if they satisfied with services provided by the XYZNet portal.

There are two kinds of recommendation that the author would like to propose. The first recommendation is for future researchers, and the second one is for PT Asuransi XYZ Indonesia.

\section{RECOMMENDATIONS}

\section{For Future Study}

First, in this study the author only focuses on three variables, namely service quality, satisfaction, and loyalty. In order to get more accurate and diverse data, the future researchers can add several variables such as brand image, price of the product, purchase intention, customer financial conditions, psychology, and many more.

Second, in this study the author limited participants to 100 samples. In order to generate higher quality research, it is highly advised to conduct a similar test using a greater number of samples, so that better answers from respondents will be obtained.

Third, in this study, sampling was limited to the user with minimum five case. In order to get more various and comprehensive data, the author suggest sampling with only minimum one case. So, it will bring the result from new user and deeper result.

\section{For PT Asuransi XYZ Indonesia}

First, to achieve higher agents' satisfaction and agents' loyalty, XYZNet is recommended to improve service quality. For example, XYZNet should provide more modular product, so the agents can adjust the product based on their customer request.

Second, to increase number of user, need massive training and socialization about how to use the XYZNet, and what kind of benefit for the agents if the use this tools, for example quotation or covernote can be created and delivered to email in the short time, no necessary wasting time to go to office to get that document, and many more.

Third, need strong commitment from management of Asuransi XYZ if they want to increase number of usage, where they must eager to stop entertain offline submission for the product that available in XYZNet.

\section{REFERENCES}

Abdillah, W., \& Hartono, J. (2015). Partial Least Square (PLS) Alternatif Structural Equation Modeling (SEM) Dalam Penelitian Bisnis. Yogyakarta: Andi Offset.

Anderson, R. E., \& Srinivasan, S. S. (2003). E-Satisfaction and E-Loyalty: A Contingency Framework. Psychology and Marketing.https://doi.org/10.1002/mar.10063

Barnes, S., \& Vidgen, R. (2002). An integrative approach to the assessment of e-commerce quality. Journal of Electronic Commerce Research. 
Catlin, T., Khanna, S., Lorenz, J.-T., \& Sultan, S. S. (2016). Making digital strategy a reality in insurance. Retrieved September 27, 2019, from https://www.mckinsey.com

Evanschitzky, H., Iyer, G. R., Hesse, J., \& Ahlert, D. (2004). E-satisfaction: A re-examination. Journal of Retailing. https://doi.org/10.1016/j.jretai.2004.08.002

Ghalandari, K. (2012). The Effect of E-Service Quality on E-Trust and E-Satisfaction as Key Factors Influencing Creation of E-Loyalty in E-Business Context: The Moderating Role of Situational Factors. J. Basic. Appl. Sci. Res.

Ghozali, I. (2014). Structural Equation Modeling, Metode Alternatif dengan Partial Least Square (PLS). (Keempat). Semarang: Badan Penerbit Universitas Diponegoro.

Gounaris, S., Dimitriadis, S., \& Stathakopoulos, V. (2010). An examination of the effects of service quality and satisfaction on customers' behavioral intentions in e-shopping. Journal of Services Marketing. https://doi.org/10.1108/08876041011031118

Kotler, P., \& Armstrong, G. (2014). Principles of Marketing (14th ed.). England: Pearson Education, Inc. Kotler, P., \& Keller, K. L. (2016). Marketing Management (6th ed.). England: Pearson Education, Inc. Kundu, S., \& Datta, S. K. (2015). Impact of trust on the relationship of e-service quality and customer satisfaction. Euro Med Journal of Business. https://doi.org/10.1108/EMJB-10-2013-0053

Lee, G. G., \& Lin, H. F. (2005). Customer perceptions of e-service quality in online shopping. International Journal of Retail and Distribution Management. https://doi.org/10.1108/09590550510581485

Lin, G. T. R., \& Sun, C. C. (2009). Factors influencing satisfaction and loyalty in online shopping: An integrated model. Online Information Review. https://doi.org/10.1108/14684520910969907

Link, J., \& Hildebrand, V. (1993). Database Marketing und Computer Aided Selling. Munich: Vahlen.

Loiacono, E., Watson, R. T., \& Goodhue, D. (2002). WebQualTM: A Web Site Quality Instrument. American Marketing Association: Winter Marketing Educators' Conference. https://doi.org/10.16953/deusbed.74839

Lu, J., Shambour, Q., Xu, Y., Lin, Q., \& Zhang, G. (2010). BizSeeker: A hybrid semantic recommendation system for personalized government-to-business e-services. Internet Research, 20(3), 342-365. https://doi.org/10.1108/10662241011050740

Muhammad, A. (2006). Hukum Asuransi Indonesia. Bandung: Citra Aditya Bakti.

Mullins, R. R., Ahearne, M., Lam, S. K., Hall, Z. R., \& Boichuk, J. P. (2014). Know your customer: How salesperson perceptions of customer relationship quality form and influence account profitability. Journal of Marketing. https://doi.org/10.1509/jm.13.0300

Oliver, R. L. (1997). A Behavioral Perspective on the Consumer. New York: Irwin/McGraw-Hill.

Oliver, R. L. (2010). Satisfaction: A behavioral perspective on the consumer (2nd Editio). New York: M.E.Sharpe.

Parasuraman, A., Zeithaml, V. A., \& Malhotra, A. (2005a). A conceptual framework for understanding E-service quality: Implications for future research and managerial practice. Journal of Service Research. https://doi.org/10.1177/1094670504271156

Parasuraman, A., Zeithaml, V. A., \& Malhotra, A. (2005b). E-S-QUAL a multiple-item scale for assessing electronic service quality. Journal of Service Research. https://doi.org/10.1177/1094670504271156

Purnamasari, D. (2018). The Roles of E-Service Quality , E-Trust , and E-Satisfaction on Online Retail Loyalty. Industrial Research Workshop and National Seminar.

Reicheld, F. F., Markey, R. G., \& Hopton, C. (2000). E-customer loyalty - applying the traditional rules of business for online success. European Business Journal.

Sharma, G. (2017). Service Quality, Satisfaction and Loyalty on Online Marketing: An Empirical Investigation. Global Journal of Management and Business Research,17(2).

Silalahi, U. (2009). Metode Penelitian Sosial. Jakarta: Refika Aditama.

Sousa, R., \& Voss, C. A. (2006). Service quality in multichannel services employing virtual channels. Journal of Service Research. https://doi.org/10.1177/1094670506286324 
Struntz, J., Poppleton, A., \& Lees, C.(2019). Digital Transformation Remaking an Industry. Oxford.

Sugiyono. (2016). Metode Penelitian Pendidikan, Pendekatan Kuantitatif, Kualitatif, dan R\&D. Bandung: Alfabeta.

Szymanski, D. M., \& Hise, R. T. (2000). E-satisfaction: An initial examination. Journal of Retailing. https://doi.org/10.1016/S0022-4359(00)00035-X

Wolfinbarger, M., \& Gilly, M. C. (2003). eTailQ: Dimensionalizing, measuring and predicting etail quality. Journal of Retailing. https://doi.org/10.1016/S0022-4359(03)00034-4

Yazid. (2008). Pemasaran Jasa (Kedua). Yogyakarta: Ekonisia Kampus.

Yi, Y., \& La, S. (2004). What Influences the Relationship between Customer Satisfaction and Repurchase Intention? Investigating the Effects of Adjusted Expectations and Customer Loyalty. Psychology and Marketing. https://doi.org/10.1002/mar.20009

Yoo, B., \& Donthu, N. (2001). Developing a Scale to Measure the Perceived Quality of an Internet Shopping Site (SITEQUAL). Quarterly Journal of Electronic Commerce.

Zeithaml, V. A., Berry, L. L., \& Parasuraman, A. (1996). The behavioral consequences of service quality. Journal of Marketing.https://doi.org/10.2307/1251929

Zeithaml, V. A., Parasuraman, A., \& Malhotra, A. (2000). e-Service Quality: Definition, Dimensions and Conceptual Model. Working Paper, (Marketing Science Institute, Cambridge).

Zeithaml, V. A., Parasuraman, A., \& Malhotra, A. (2002). An empirical examination of the service qualityvalue-loyalty chain in an electronic channel. Working Paper, (University of North Caroline). 